\title{
EFEK MEDIASI VARIABEL WORK ENGAGEMENT DALAM PENGARUH JOB RESOURCEFULNESS TERHADAP INDIVIDUAL CRAFTING DAN COLLABORATIVE CRAFTING
}

\author{
Yahdi Ariski \\ Universitas Negeri Surabaya \\ yahdi.17080574041@mhs.unesa.ac.id \\ Dwiarko Nugrohoseno \\ Universitas Negeri Surabaya \\ dwiarkonugrohoseno@unesa.ac.id
}

Abstract

\begin{abstract}
This study examines the influence of job resourcefulness on individual crafting and collaborative crafting through work engagement as a mediator variable. This research uses a quantitative approach, using a survey to collect data. The sample in this study amounted to 100 employees from 4-star hotels throughout Surabaya who are registered in the Traveloka. This research used Structural Equation Model (SEM) with the assistance of Smart PLS 3.0 software as the statistical analysis. This research shows that job resourcefulness has a significant positive direct influence on individual crafting and has a significant and positive individual influence on individual crafting through work engagement on 4-star hotel employees. Job resourcefulness is found to have a significant and negative direct influence on collaborative crafting. Job resourcefulness has a significantly direct indirect influence on collaborative crafting through work engagement with 4-star hotel employees. The implications of this study need to increase the collaborative crafting employees by involving all employees in the procurement of discussion forums, so they can harmonize the thought between employees in the company so that the existence of the forum there will be similarities of perceptions so that work collaboration can be well established.
\end{abstract}

Keywords: collaborative crafting; individual crafting; job resourcefulness; work engagement.

\section{PENDAHULUAN}

Penyebaran Covid-19 di Indonesia pertama kalinya diumumkan pemerintah pada tanggal 2 Maret 2020 (Pranita, 2020). Sampai dengan 2 Juni 2021 ini, pemerintah melalui data dari Satgas bidang penanganan Covid-19 mencatat hingga 1.837.126 orang yang terinfeksi covid-19 sejak kasus pertama dilaporkan pada awal maret kemarin, sedangkan pasien yang sembuh berjumlah 1.680 .501 orang, serta data yang meninggal dunia sebesar 51.095 orang (Abdulah, 2021). Tidak hanya berdampak terhadap kesehatan seseorang, namun virus ini juga menurunkan perekonomian dari sektor makro hingga mikro, dan sektor yang memiliki efek cukup berat adalah pada sektor pariwisata. Dari data BPS (2020), tingkat penurunan yang terbesar terjadi adalah turis dari Singapura yakni sebesar 33,12\% dan turis dari Malaysia 13,87\%. Komponen lainnya adalah Tingkat Penghunian Kamar (TPK) hotel yang turun sebesar 10,22 poin mtm dan 2,3 poin yoy. Estimasi kerugian di sektor pariwisata sebesar hampir Rp 7 triliun per bulan (Pebrianto, 2020). Selama pandemi ini, diperkirakan lebih kurang dua ribu hotel dinyatakan tutup operasional dan sebesar lebih kurang delapan ribu restoran mengalami kejadian yang sama dikarenakan penurunan omset akibat tidak adanya kunjungan wisatawan. Faktor selanjutnya adalah tidak efektifnya solusi pemerintah kepada sektor pariwisata untuk mengurangi biaya operasional perusahaan yang sebagian besar komponen biaya tersebut adalah upah para pekerja, serta program kartu pra-kerja yang diadakan pemerintah juga kurang efisien dikarenakan banyak pekerja justru tidak dapat mengakses program kartu pra-kerja tersebut dikarenakan pada dasarnya pada kondisi saat ini yang dibutuhkan adalah bantuan langsung secara tunai (Wahyudi, 2020).

Di tengah mewabahnya virus Covid-19 dan keterpurukan bisnis yang ada di Indonesia, pemerintah mencanangkan adanya era baru yakni new normal atau masa kebangkitan dari adanya pandemi yang diharapkan dapat meningkatkan atau memulihkan kembali laju perekonomian Indonesia di mana semua perusahaan yang beroperasi wajib menaati dan melakukan penyesuaian terhadap aturan 
Yahdi Ariski \& Dwiarko Nugrohoseno. Efek Mediasi Variabel Work Engagement dalam Pengaruh Job Resourcefulness terhadap Individual Crafting dan Collaborative Crafting

pemerintah yang telah ditetapkan dalam pengupayaan keamaan dan kenyamanan kepada pekerja maupun pelanggan. Selain itu, perubahan dan persiapan strategi baru berbasis digital juga perlu diterapkan perusahaan karena pelanggan saat ini mulai terbiasa dengan digitalisasi (SWAonline, 2020). Dengan strategi ini, hotel tetap dapat mengupayakan layanan inap lebih aman, seamless, dan juga contactless dengan beberapa strategi dan inisiatif baru seperti sanitized stay, layanan check-in dan check-out tanpa sentuhan, serta pembayaran menggunakan teknologi e-wallet (Anggita, 2020).

Traveloka adalah salah satu perusahaan yang telah menerapkan strategi digital tersebut. Traveloka merupakan salah satu perusahaan terkemuka di bidang travel yang menyediakan berbagai kebutuhan perjalanan dalam satu platform yang menawarkan tiket pesawat, hotel tiket kereta, paket pesawat dan hotel, transportasi bandara, bus dan rental mobil khusus di Indonesia secara online. Dengan adanya hotel yang bekerja sama dengan Traveloka hotel, hotel semakin dimudahkan dalam kegiatan operasional dalam mencari pelanggan karena Traveloka memiliki jangkauan yang lebih luas, menggunakan teknologi modern seperti booking secara online, dan menyediakan berbagai metode pembayaran (Traveloka, 2019). Aplikasi Traveloka dalam booking hotel juga dilengkapi dengan fitur untuk mencari ketersediaan fasilitas-fasilitas seperti hotel yang dilengkapi wi-fi, parkir 24 jam, restoran, resepsionis 24 jam, parkir, lift, jalur kursi roda, pusat kebugaran, fasilitas rapat, dan antar jemput bandara. Tidak hanya itu, Traveloka juga mendapat penghargaan Most Powerful Indonesia Technology Brand dan Most Innovative Brand pada 2017 oleh merek yang bernaung di bawah perusahaan komunikasi global WPP. Penghargaan tersebut menyatakan bahwa Traveloka memiliki total $61,7 \%$ share dan menjadi perusahaan terdepan dalam kategori teknologi di Indonesia. Traveloka juga meraih nilai merek tertinggi dibandingkan dengan perusahaan private online lain di Indonesia, yaitu sebesar 33\% (Traveloka Team, 2020).

Aplikasi Traveloka juga memiliki fitur yang lengkap dibandingkan dengan aplikasi lain. Pada Traveloka, pengguna dapat melihat atau mensortir hotel berdasarkan klasifikasi bintang dan kelasnya. Keunggulan inilah yang dijadikan dasar untuk memilih Traveloka menjadi objek pada studi ini. Dengan adanya fitur booking hotel secara online, fitur fasilitas dan kemudahan dalam membandingkan harga dari traveloka, bahkan fitur potongan harga oleh Traveloka menyebabkan peningkatan TPK (Tingkat Penghunian Kamar) dalam hotel berbintang karena adanya kemudahan booking dan bertransaksi tanpa bertemu secara tatap muka, khususnya dalam hotel bintang 4 (Traveloka, 2019).

Tabel 1. TPK MENURUT KLASIFIKASI BINTANG DI INDONESIA, DESEMBER 2020.

\begin{tabular}{cccccc}
\hline $\begin{array}{c}\text { Klasifikasi } \\
\text { Bintang }\end{array}$ & $\begin{array}{c}\text { Des 2019 } \\
(\boldsymbol{\%})\end{array}$ & $\begin{array}{c}\text { Nov 2020 } \\
(\boldsymbol{\%})\end{array}$ & $\begin{array}{c}\text { Des 2020 } \\
(\boldsymbol{\%})\end{array}$ & $\begin{array}{c}\text { Perubahan Des 2020 } \\
\text { dan Des 2019 (poin) }\end{array}$ & $\begin{array}{c}\text { Perubahan Des 2020 } \\
\text { dan Nov 2020 (poin) }\end{array}$ \\
\hline Bintang 1 & 42,36 & 29,03 & 28,08 & $-14,28$ & $-0,95$ \\
Bintang 2 & 58,58 & 38,99 & 39,55 & $-19,03$ & 0,56 \\
Bintang 3 & 57,40 & 42,03 & 41,14 & $-16,26$ & $-0,89$ \\
Bintang 4 & 63,34 & 41,91 & 43,54 & $-19,80$ & 1,63 \\
Bintang 5 & 62,87 & 35,37 & 38,43 & $-24,44$ & 3,06 \\
Seluruh & 59,39 & 40,14 & 40,79 & $-18,60$ & 0,65 \\
Bintang & & & & & \\
\hline
\end{tabular}

Sumber: Badan Pusat Statistik (2021)

Tabel 1 menjelaskan di tahun 2020 hotel yang berbintang 4 memiliki TPK terbesar diantara hotel berbintang lainnya, keunggulan nilai-nilai okupansi yang dimiliki hotel bintang mempunyai beberapa alasan, dari berbagai segi bintang hotel lebih memberikan penawaran yang menarik kepada konsumen untuk merasakan pengalaman tersebut. Dari segi lokasi, hotel bintang cenderung memiliki lokasi yang dekat dengan tempat perbelanjaan, pusat kota, dan pusat transportasi. Alasan tersebut yang mendasari studi ini menggunakan hotel bintang 4 dikarenakan Tingkat Penghunian Kamar yang memiliki angka paling signifikan di tahun 2020 adalah hotel bintang 4 sehingga dalam masa pandemi ini strategi hotel bintang 4 sangat memengaruhi TPK dari hotel berbintang lainnya (Jayani, 2020). 
Karyawan dalam melaksanakan tugasnya dituntut memiliki kinerja yang baik dalam melakukan tugas pekerjaannya, dan pada masa pandemi ini tentunya banyak perubahan dan tuntutan yang secara garis besar dapat terjadi sewaktu-waktu serta tidak dapat diprediksi. Sehingga, karyawan harus mampu memiliki kesadaran untuk menuntaskan pekerjaannya secara cepat dan tepat walaupun cara yang digunakan dalam menyelesaikan pekerjaannya merupakan inisiatif dari karyawan sendiri. Proses mengubah batasan pekerjaan dan mendesain ulang pekerjaannya dengan cara pribadi ini disebut $J o b$ crafting (Wrzesniewski \& Dutton, 2001). Dengan job crafting tersebut, karyawan dapat menuntaskan pekerjaan seoptimal mungkin, serta diharapkan selalu cepat beradaptasi dengan situasi pandemi saat ini agar dapat menyelesaikan hambatan pekerjaan yang sewaktu-waktu ditemui untuk mendukung dan mencapai keberhasilan perusahaannya dalam menggapai visi misi dan tujuan yang telah direncanakan (Tims et al., 2012).

Pengaruh positif job resourcefulness terhadap individual crafting pada karyawan perhotelan dibuktikan oleh Chen (2019). Karyawan hotel tersebut mengalami permasalahan dalam pekerjaannya sewaktu-waktu. Karyawan dengan job resourcefulness tinggi akan mendorong keinginan karyawan dalam mengubah prosedur pekerjaan, meningkatkan kapasitas, dan kemampuan mereka untuk menyelesaian pekerjaannya (individual crafting) dalam kondisi dengan sumber daya yang terbatas sebaik-baiknya.

Hasil penelitian yang berbeda diperoleh Wang et al. (2016) bahwa karyawan dengan job resourcefulness yang tinggi dapat menentukan serta memiliki strategi yang berbeda-beda untuk menyusun pekerjaan mereka, tetapi tidak semua strategi job crafting tersebut akan membawa hasil yang positif dan mencapai apa yang diinginkan dari setiap karyawan tersebut, salah satu penyebabnya adalah kelelahan dan tekanan pekerjaan yang banyak, sehingga apabila karyawan mengalami kelelahan akan mengurangi tuntutan pekerjaan yang direncanakan serta berdampak terhadap tidak efektifnya strategi mereka.

Studi Alonso \& Topa (2019) menyebutkan bahwa work engagement berpengaruh terhadap job crafting. Karyawan dengan tingkat individual crafting yang tinggi terlibat dalam aktivitas atau strategi pekerjaannya akan meningkatkan juga keterlibatannya dalam collaborative crafting dan mengakibatkan tingkat work engagement juga akan meningkat secara signifikan dikarenakan skala yang digunakan pada individual crafting dan collaborative crafting adalah valid dan menjadi dua hal yang tidak bisa disamakan. Sedangkan, studi oleh Fazriati \& Budiono (2017) menyatakan bahwa tidak adanya pengaruh antara variabel work engagement terhadap job crafting karena tidak semua karyawan menerapkan dan melakukan collaborative crafting dalam pekerjaannya, dan untuk membuat karyawan memiliki work engagement dalam pekerjaannya dapat juga dipengaruhi oleh lingkungan yang nyaman dalam pekerjaannya maka karyawan tersebut akan merasa adanya dorongan positif serta merasa engaged dengan pekerjaannya.

Tujuan penelitian ini adalah untuk menganalisis serta menguji efek mediasi variabel work engagement dalam pengaruh job resourcefulness terhadap individual crafting dan collaborative crafting.

\section{KAJIAN PUSTAKA DAN PENGEMBANGAN HIPOTESIS}

\section{Job Resourcefulness}

Licata et al. (2003) berpendapat job resourcefulness merupakan disposisi atau kecenderungan sikap seseorang dalam memanfaatkan sumber daya yang terbatas untuk menghadapi serta menyelesaikan suatu pekerjaan. Menurut Karatepe \& Aga (2012), job resourcefulness adalah sikap yang dilakukan karyawan untuk mencapai tujuan menyelesaikan pekerjaan mereka dengan keterbatasan sumber daya yang ada dalam lingkungan kerja organisasinya. Secara tidak langsung, para karyawan dengan job resourcefulness yang tinggi, akan memiliki banyak akal, ide, dan pikiran dalam mengolah sumber daya yang terbatas serta mengatasi hambatan dalam pekerjaan untuk mencapai keberhasilan. Ashill et al. (2020) menjelaskan bahwa job resourcefulness dihasilkan dari adanya tekanan untuk bertindak 
Yahdi Ariski \& Dwiarko Nugrohoseno. Efek Mediasi Variabel Work Engagement dalam Pengaruh Job Resourcefulness terhadap Individual Crafting dan Collaborative Crafting

dengan cara tertentu dalam situasi tertekan dan berhubungan dengan ciri-ciri kepribadian seseorang yaitu kesadaran, keterbukaan terhadap pengalaman, stabilitas emosional, dan kebutuhan aktivitas.

\section{Individual Crafting}

Konsep individual crafting dan collaborative crafting berasal dari dimensi job crafting yang mana kedua variabel ini memenuhi kriteria tersebut karena dapat diukur secara individu ataupun tim. Individual crafting merupakan proses untuk merubah batasan tugas dalam pekerjaannya sesuai dengan preferensi dan kompetensi dari suatu individu dalam perusahaannya agar lebih cocok dan sesuai (Leana et al., 2009). Salah satu faktor yang memengaruhi dari individual crafting seseorang menurut Tims \& Bakker (2010) adalah person job-fit, yaitu kecocokan ataupun sesuai atau tidaknya antara pengetahuan, kemampuan, serta keterampilan seseorang dengan pekerjaan yang dilakukan dalam perusahaan.

\section{Collaborative Crafting}

Perspektif dalam collaborative crafting berisi tentang suatu kelompok karyawan bekerja sama meninjau, merubah, dan membuat kesepakatan dari tugas pekerjaan mereka dalam suatu perusahaan sesuai dengan preferensi bersama dari setiap kelompok pekerjaan (Leana et al., 2009). Faktor yang memengaruhi variabel ini menurut Wrzesniewski \& Dutton (2001) di antaranya adalah kebutuhan control, citra diri yang positif, dan kebutuhan interaksi sosial. Kebutuhan kontrol meliputi kecenderungan seseorang atau kelompok pekerjaan mengendalikan sesuatu yang mereka kerjakan agar dapat menguasai dan menyelesaikan pekerjaan dengan cara yang telah disepakati bersama. Citra diri yang positif berkaitan dengan kelompok pekerjaan yang cenderung melindungi citra positif yang ada dalam diri masing-masing dengan cara merubah batasan pekerjaan mereka terhadap preferensi masing-masing. Sedangkan, faktor interaksi sosial berhubungan dengan interaksi mereka antara seseorang dengan orang lainnya ditujukkan untuk mencari relasi baru serta diharapkan dapat saling membantu pekerjaan satu sama lain (Chen, 2019).

\section{Work Engagement}

Schaufeli et al. (2002) dalam studinya mengatakan bahwa work engagement merupakan keadaan pikiran yang postif, afektif, dan terkait dengan pekerjaannya. Sifat tersebut berkaitan dengan penilaian kemampuan seseorang yang dilihat dari sukap dan nilai sosial yang diterapkan dalam perusahaan. Beberapa faktor yang memengaruhi work engagement menurut Bakker \& Leiter (2010) di antaranya adalah job resource, job demands, dan personal resource. Hal yang berkaitan dengan job resource adalah pencapaian pekerjaan, pengurangan efek tuntutan dalam bekerja, dan pengembangan pribadi seseorang. Sedangkan, job demands memfokuskan pada sosial, fisik, dan organisasi pada pekerjaan yang membutuhkan usaha fisik dan mental, contohnya adalah tingginya tekanan pada pekerjaan. Personal resource dijelaskan sebagai evaluasi positif yang berkaitan dengan kekuatan dan daya tahan seseorang dalam mengontrol serta memberikan dampak pada sekitarnya (Tims et al., 2013a).

\section{Hubungan antar Variabel}

Ashill et al. (2009) menjelaskan bahwa job resourcefulness dikaitkan dengan sikap banyak akal, ide, dan pikiran seseorang dalam mengatasi tekanan dalam pekerjaannya serta bertindak positif dalam situasi tertentu. Tindakan seseorang dalam mengatasi tekanan dalam pekerjaan merupakan suatu perubahan batasan dan termasuk pada ciri dari job crafting yakni inisiatif karyawan dalam menyesuaikan kondisi kerjanya (Wrzesniewski \& Dutton, 2001). Secara khusus, karyawan yang memiliki banyak pekerjaan cenderung memenuhi tujuan kerja mereka meskipun menggunakan cara mereka sendiri, sehingga aspek banyak akal dalam job resourcefulness terkait dengan job crafting (Semedo et al., 2016).

Temuan dari Tims et al. (2013b) menyatakan bahwa karyawan yang menyusun job resource pada bulan pertama pada saat pelaksanaan studinya menunjukkan bahwa adanya peningkatkan dalam structural job resource dan social job resource (indikator job crafting). Studi tersebut juga menyarankan bahwa perusahaan harus memberi kebebasan pada karyawan dalam melakukan perubahan batasan tugasnya atau memberikan ruang pada karyawan untuk menyelesaikan pekerjaan 
dengan caranya sendiri karena secara tidak langsung karyawan akan terpacu dan menggunakan sikap banyak akal, ide, dan pikirannya terhadap penyelesaikan pekerjaannya (job crafting).

\section{H1: Job resourcefulness berpengaruh signifikan positif terhadap individual crafting.}

$\mathrm{H} 2$ : Job resourcefulness berpengaruh signifikan positif terhadap collaborative crafting.

Karatepe \& Karadas (2015) menjelaskan dalam studinya, ketika karyawan dapat dengan benar mengolah dan memelihara sumber dayanya dengan baik, maka karyawan tersebut dipastikan dapat mengatasi masalah atau hambatan yang ditemuinya dalam pekerjaan. Maka, karyawan ini dapat dikatakan memiliki engagement dalam pekerjaannya. Pernyataan tersebut didukung dengan adanya temuan hasil studi oleh Bakker (2017) bahwa sumber daya pribadi (optimisme dan efikasi diri) berhubungan positif dengan keterikatan kerja karena sumber daya pribadi memiliki fungsi intrinsic untuk menyelesaikan tujuan terkait pekerjaan dan meningkatkan pengembangan karier sehingga semakin besar sumber daya yang dimiliki seseorang dalam pekerjaannya, maka semakin meningkat work engagement tersebut dalam pekerjaannya.

Rod \& Ashill (2009) menjelaskan bahwa job resourcefulness dan sifat kepribadian situasional dipandang sebagai sumber daya yang wajib dimiliki oleh individu, maka dari itu pengaruh job resourcefulness terhadap work engagement dapat dijelaskan menggunakan teori COR karena karyawan dengan job resourcefulness yang tinggi memiliki kecenderungan intrinsik untuk mencapai tujuan kerja, serta kecenderungan ini merupakan karakteristik dari fungsi sumber daya pribadi (Chen, 2019).

\section{H3: Job resourcefulness berpengaruh signifikan positif terhadap work engagement.}

Studi oleh Garg \& Dhar (2017) menemukan bahwa work engagement merupakan salah satu anteseden dari employee work behavior. Berdasarkan Teori COR, karyawan berusaha untuk meningkatkan sumber daya mereka untuk mencapai tujuan kerja dan mencapai hasil yang positif (Xanthopoulou et al., 2009). Maka, karyawan yang memiliki work engagement secara proaktif mengubah kondisi kerja mereka dan perilaku untuk mengubah kondisi kerja merupakan salah satu faktor dari Job Crafting (Lu et al., 2014). Karyawan dengan tingkat work engagement yang tinggi cenderung memobilisasi sumber daya oekerjaan mereka dan cenderung menunjukkan inisiatif pribadi dalam menyelesaikan pekerjaannya (Sonnentag, 2003). Salah satu ciri utama dari job crafting yang dijelaskan dalam studi Wrzesniewski \& Dutton (2001) adalah inisiatif karyawan untuk menyesuaikan kondisi kerjanya. Oleh karena itu, work engagement dapat dikaitkan dengan peringkat rekan kerja dari job crafting secara positif (Tims et al., 2012). Dengan kata lain, karyawan dengan work engagement yang tinggi cenderung proaktif untuk menyusun situasi kerja mereka untuk mempertahankan engagement mereka dalam pekerjaannya (Bakker et al., 2012).

Studi dari beberapa para ahli telah membuktikan bahwa work engagement memilki hubungan terhadap job crafting di level individual dan kolaboratif (tim). Lu et al. (2014) dalam studinya menjelaskan bahwa work engagement berhubungan positif dengan job crafting dalam pekerjaan relasional. Alonso \& Topa (2019) juga menjelaskan temuannya bahwa karyawan dengan tingkat individual crafting yang lebih tinggi terlibat dalam aktivitas dan strategi yang menghasilkan tingkat collaborative crafting yang lebih tinggi, dan mengakibatkan work engagement serta job satisfaction juga akan semakin meningkat, dan menyarankan bahwa perusahaan harus berusaha untuk mendorong iklim kerja yang kondusif untuk aktivitas yang dirancang untuk meningkatkan keahlian kerja dan meningkatkan engagement. Studi dari Chen (2019) menjelaskan temuannya bahwa karyawan hotel yang terlibat cenderung membentuk kembali pekerjaan mereka secara individual dan kolaboratif. Selain itu, karyawan dengan work engagement yang tinggi, berkomitmen terhadap pekerjaan mereka, dan karyawan akan mengubah batasan kerja mereka sendiri yaitu melalui individual crafting atau memodifikasi batas pekerjaan dengan rekan kerja mereka untuk mencapai tujuan kerja bersama melalui collaborative crafting. 
Yahdi Ariski \& Dwiarko Nugrohoseno. Efek Mediasi Variabel Work Engagement dalam Pengaruh Job Resourcefulness terhadap Individual Crafting dan Collaborative Crafting

H4: Work engagement berpengaruh signifikan positif terhadap individual crafting.

H5: Work engagement berpengaruh signifikan positif terhadap collaborative crafting.

Job resourcefulness yang dimiliki oleh karyawan muncul dari adanya motivasi intrinsik untuk mencapai tujuan penyelesaian pekerjannya (Semedo et al., 2016). Kecenderungan ini membuat karyawan memiliki engagement pada pekerjannya, merasakan adanya semangat, penyerapan dan dedikasi terhadap pekerjannya (Karatepe \& Aga, 2012). Oleh karena itu, karyawan yang memiliki job resourcefulness yang tinggi menunjukkan adanya perilaku proaktif terhadap pekerjaan mereka. Artinya, work engagement dapat berfungsi sebagai mekanisme penjelas untuk hubungan antara job resourcefulness terhadap job crafting (Chen, 2019). Dari sudut pandang mediasi, work engagement dapat menjadi mediator penting dalam hubungan antara job resourcefulness dan job crafting (Arasli $e t$ al., 2017).

Temuan dalam studi Alonso \& Topa (2019) menjelaskan bahwa work engagement dapat menjadi mediator dalam job crafting di semua level (individual dan collaborative). Hal ini disebabkan karena work engagement melibatkan proses psikologis penting di mana job resourcefulness memengaruhi individual crafting dan collaborative crafting. Selain itu, karena hubungan yang lebih siginifikan adalah pengaruh job resourcefulness terhadap individual crafting melalui work engagement, maka manajer harus menyediakan sumber daya yang dibutuhkan karyawan yang memiliki pekerjaan dengan tim untuk meningkatkan work engagement mereka (Chen, 2019).

H6: Pengaruh job resourcefulness terhadap individual crafting di mediasi oleh work engagement secara signifikan.

H7: Pengaruh job resourcefulness terhadap collaborative crafting di mediasi oleh work engagement secara signifikan.

Hubungan antar variabel juga digambarkan di model penelitian pada Gambar 2.

\section{METODE PENELITIAN}

Studi ini menggunakan pendekatan kuantitatif dan jenis studi merupakan penelitian kausal. Sampel dalam studi ini adalah karyawan Hotel bintang 4 di Kota Surabaya versi Traveloka sebesar 100 orang karyawan yang mengisi kuesioner. Hubungan Variabel penelitian ini adalah pengaruh job resourcefulness terhadap collaborative crafting dimediasi oleh work engagement menggunakan teknik purposive sampling yang merupakan teknik pengambilan sampel dengan kesesuaian karakteristik pada kriteria sampel yang telah ditentukan, dan kriteria tersebut adalah seluruh Hotel bintang 4 di Kota Surabaya yang terdaftar pada aplikasi Traveloka. Teknik pengumpulan data yang digunakan adalah kuesioner dengan skala Likert 1-5 dengan kritertia mulai dari sangat tidak setuju hingga sangat setuju. Analisis statistik yang digunakan dalam pengujian seluruh variabel pada studi ini adalah Structural Equation Modelling (SEM) dengan software SmartPLS versi 3.0.

\section{HASIL DAN PEMBAHASAN}

\section{Uji Validitas}

Pengujian validitas dari tiap indikator variabel dalam kuesioner telah menghasilkan nilai yang baik (valid). Validitas dapat dilihat apabila hasilouter loading $>0,50$. Model konstruk dikatakan valid jika seluruh indikator memenuhi convergent validity (Ghozali, 2016:52).

\section{Composite Reliability}

Suatu variabel dapat memenuhi reliabilitas jika kriteria composite reliability $>0,70$. Hasil dari uji reliabilitas telah menghasilkan nilai reliabilitas yang baik karena memenuhi kriteria yaitu hasil yang diperoleh >0,70 (Ghozali, 2016:47). 


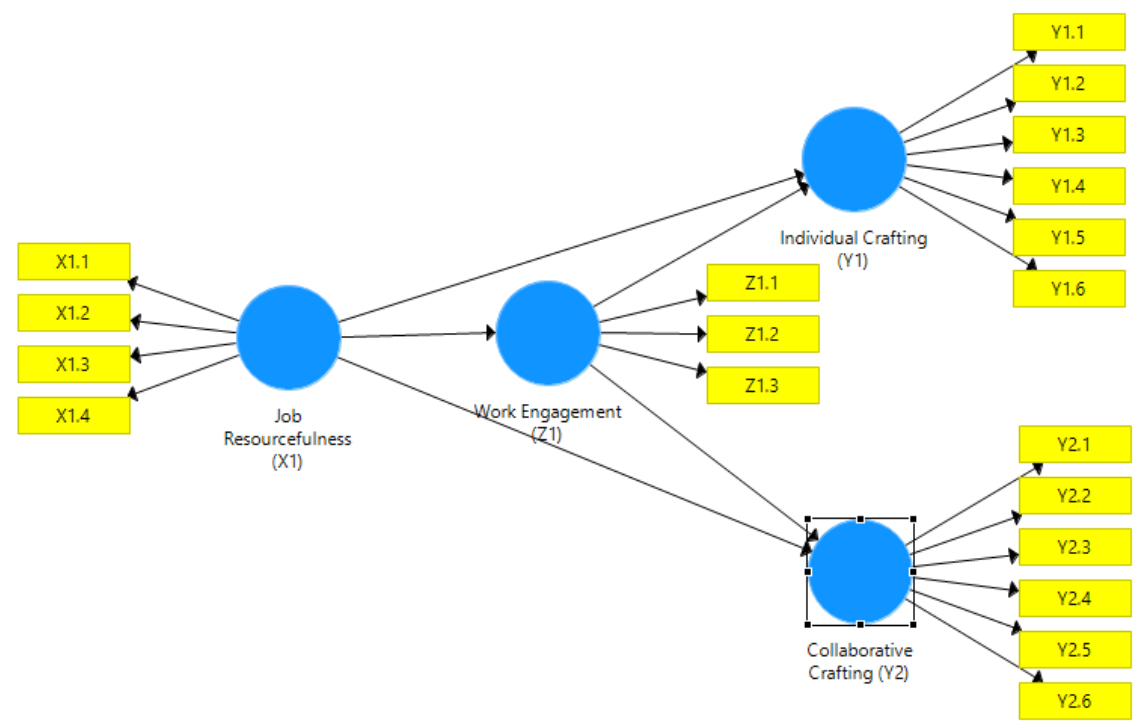

Sumber: Output SmartPLS 3.3 (2021)

Gambar 2. MODEL PENELITIAN

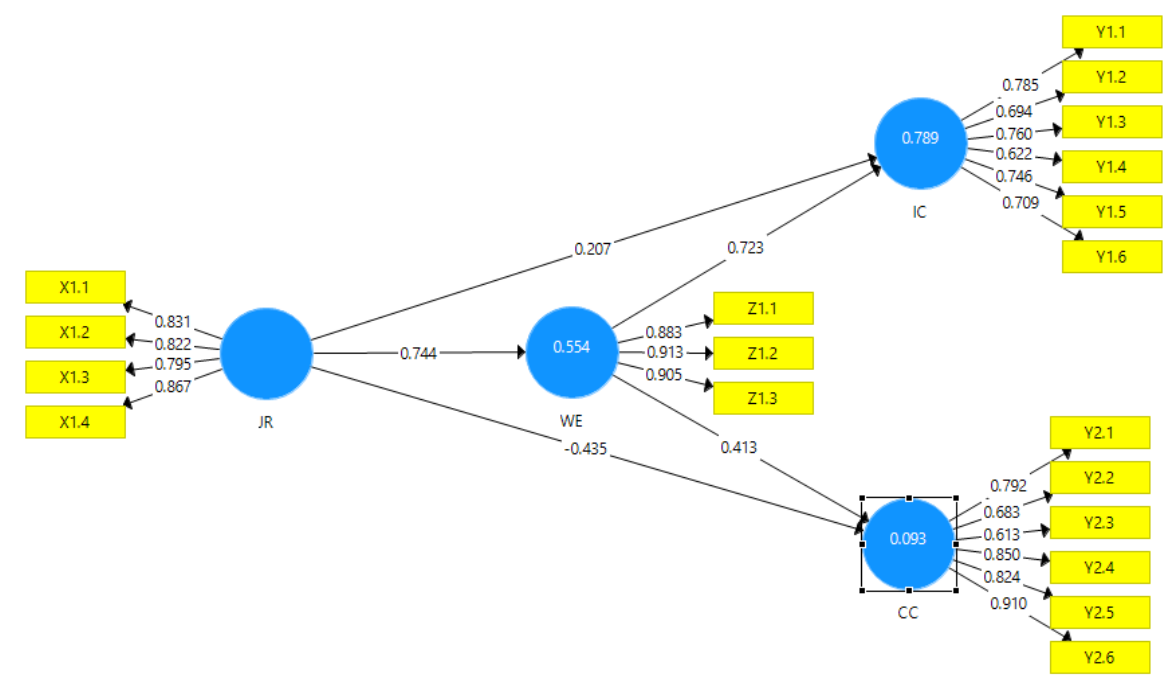

Sumber: Output SmartPLS 3.3 (2021)

Gambar 3. UJI MEASUREMENT MODEL

\section{Cronbach's Alpha}

Nilai cronbach's alpha mampu mendukung uji reliabilitas. Variabel disebut reliable apabila besarnya nilai cronbach's alpha $>0,60$. Hasil memiliki nilai reliabilitas yang baik karena telah memenuhi syarat yang ditentukan. Cronbach's alpha yang tinggi menunjukkan seluruh variabel telah memiliki tarafreliabel yang tinggi (Siregar, 2014).

\section{Analisis R-Square}

Pengujian $R$-Square digunakan sebagai penentu seberapa baik inner model yang dibentuk (Ghozali, 2014:158). Output SmartPLS 3.0 yang diolah menghasilkan pengaruh job resourcefulness terhadap individual crafting menunjukkan koefisien yang bernilai 0,789. Artinya, individual crafting dapat dijelaskan oleh variabel job resourcefulness sejumlah 78,9\% dan sebesar $21,1 \%$ dapat dijelaskan oleh variabel lain yang tidak diteliti pada studi ini. Sedangkan, model pengaruh job resourcefulness terhadap collaborative crafting menunjukkan koefisien yang bernilai 0,093 sehingga di 
Yahdi Ariski \& Dwiarko Nugrohoseno. Efek Mediasi Variabel Work Engagement dalam Pengaruh Job Resourcefulness terhadap Individual Crafting dan Collaborative Crafting

interprestasikan bahwa variabel collaborative crafting bisa dijelaskan oleh variabel job resourcefulness sejumlah 9,3\%, sedangkan sisanya dapat dijelaskan oleh variabel lain yang tidak diteliti pada studi ini. Pengaruh job resourcefulness terhadap work engagement dalam menunjukkan nilai koefisien sejumlah 0,554 yang berarti bahwa work engagement bisa didefinisikan oleh variabel job resourcefulness sejumlah $55,4 \%$.

\section{Uji Kausalitas}

Inner model digunakan untuk mengecek hubungan antara konstruk dan nilai signifikansi pada path coefficient dan hasil indirect effect pada tabel 2.

Tabel 2.

PATH COEFFICIENTS

\begin{tabular}{|c|c|c|c|c|}
\hline Pengaruh antar Variabel & Original Sample & T-Statistics & Ket & \\
\hline $\begin{array}{l}\text { job resourcefulness } \rightarrow \\
\text { individual crafting }\end{array}$ & 0,207 & 3,034 & $\begin{array}{l}\geq 1,96 \text { (tidak } \\
\text { signifikan) }\end{array}$ & $\begin{array}{l}\text { hipotesis } \\
\text { diterima }\end{array}$ \\
\hline $\begin{array}{l}\text { job resourcefulness } \rightarrow \\
\text { collaborative crafting }\end{array}$ & $-0,435$ & 2,794 & $\begin{array}{l}\geq 1,96 \text { (tidak } \\
\text { signifikan) }\end{array}$ & $\begin{array}{l}\text { hipotesis } \\
\text { ditolak }\end{array}$ \\
\hline $\begin{array}{l}\text { job resourcefulness } \rightarrow \text { work } \\
\text { engagement }\end{array}$ & 0,744 & 15,497 & $\begin{array}{l}\quad \geq 1,96 \\
\text { (signifikan) }\end{array}$ & $\begin{array}{l}\text { hipotesis } \\
\text { diterima }\end{array}$ \\
\hline $\begin{array}{l}\text { work engagement } \rightarrow \text { individual } \\
\text { crafting }\end{array}$ & 0,723 & 11,038 & $\begin{array}{l}\quad \geq 1,96 \\
\text { (signifikan) }\end{array}$ & $\begin{array}{l}\text { hipotesis } \\
\text { diterima }\end{array}$ \\
\hline $\begin{array}{l}\text { work engagement } \rightarrow \\
\text { collaborative crafting }\end{array}$ & 0,413 & 2,088 & $\begin{array}{l}\geq 1,96 \\
\text { (signifikan) }\end{array}$ & $\begin{array}{l}\text { hipotesis } \\
\text { diterima }\end{array}$ \\
\hline
\end{tabular}

Sumber: Output SmartPLS 3.0 (2021, data diolah)

Berdasarkan Tabel 2, besarnya nilai $t$-statistic job resourcefulness terhadap individual crafting adalah $3,034 \geq 1,96$. Hal tersebut menunjukan bahwa terdapat pengaruh yang positif dan signifikan. Sedangkan nilai original sample job resourcefulness terhadap collaborative crafting menunjukkan angka $-0,435$ dan nilai $t$ statistic $2,794 \geq 1,96$ yang berarti bahwa terdapat pengaruh signifikan dengan arah negatif, sehingga hipotesis kedua tidak terbukti. Nilai $t$ statistic pengaruh job resourcefulness terhadap work engagement menunjukkan $15,497 \geq 1,96$ yang berarti bahwa ada pengaruh yang positif dan signifikan dalam kedua variabel tersebut. Nilai $t$ statistic work engagement terhadap individual crafting menunjukkan hasil 11,038 $\geq 1,96$ dan terhadap collaborative crafting menunjukkan 2,088 $\geq$ 1,96 yang keduanya menunjukkan pengaruh signifikan positif.

Berdasarkan Tabel 3, besarnya nilai $t$ statistic job resourcefulness terhadap individual crafting melalui work engagement adalah $9,112 \geq 1,96$. Hasil pengujian secara indirect tersebut menunjukkan bahwa adanya pengaruh yang signifikan dan positif antara job resourcefulness terhadap individual crafting dengan melalui variabel mediasi work engagement. Nilai $t$ statistic job resourcefulness terhadap collaborative crafting melalui work engagement adalah $2,041 \geq 1,96$. Hasil tersebut menunjukkan bahwa terdapat pengaruh yang signifikan terhadap pengujian secara indirect variabel job resourcefulness terhadap collaborative crafting melalui work engagement.

\section{Pengaruh Job Resourcefulness terhadap Individual Crafting}

Job resourcefulness terbukti berpengaruh positif terhadap individual crafting. Job resourcefulness yang dimiliki oleh karyawan dapat memengaruhi karyawan tersebut dalam merubah pekerjaannya sesuai dengan preferensinya masing-masing. Hal ini juga didukung oleh studi Semedo et al. (2016) pada dasarnya karyawan yang memiliki pekerjaan cenderung untuk mencari cara sendiri untuk menyelesaikan pekerjaannya dengan baik walaupun dalam kondisi kerja dengan sumber daya yang terbatas. Temuan dalam studi Karatepe \& Aga (2012) juga menjelaskan bahwa kecenderungan karyawan yang memiliki sifat ini adalah karyawan yang bekerja di perusahaan jasa serta karyawan frontliner yang memang dalam industrinya masing-masing bertanggung jawab untuk melayani pelanggan serta mencari solusi dari setiap permasalahan yang ditemui dalam pekerjaannya. Karyawan Frontliner menghadapi kontak tatap muka dengan pelanggan dalam kondisi pekerjaannya dituntut 
memiliki banyak akal dalam memberikan layanan yang berkualitas baik serta dapat mengatasi masalah terkait pekerjaannya meskipun dalam keadaan sumber daya yang terbatas (Karatepe \& Aga, 2012).

Tabel 3.

INDIRECT EFFECTS

\begin{tabular}{lcccc}
\hline Pengaruh antar Variabel & Original Sample & T-Statistic & \multicolumn{2}{c}{ Keterangan } \\
\hline $\begin{array}{l}\text { job resourcefulness } \rightarrow \text { work engagement } \\
\rightarrow \text { individual crafting }\end{array}$ & 0,538 & 9,112 & $\geq 1,96$ & $\begin{array}{c}\text { hipotesis } \\
\text { diterima } \\
\text { job resourcefulness } \rightarrow \text { work engagement }\end{array}$ \\
$\begin{array}{l}\text { collaborative crafting } \\
\text { S }\end{array}$ & 0,307 & 2,041 & $\geq 1,96$ & $\begin{array}{c}\text { hipotesis } \\
\text { diterima }\end{array}$ \\
\hline
\end{tabular}

Sumber: Output SmartPLS 3.0 (2021, data diolah)

Yavas et al. (2011) mengungkapkan dalam studinya, karyawan dengan tingkat job resourcefulness yang tinggi cenderung lebih kuat dan tangguh dalam menghadapi kendala pekerjaannya dan dapat lebih mudah mencapai tujuannya terkait dengan pekerjaannya di lingkungan yang memiliki keterbatasan sumber daya dikarenakan mereka lebih mampu kreatif dan memodifikasi pekerjaannya sesuai dengan kompetensinya masing-masing. Hasil studi ini juga mendukung studi dari Chen, (2019) yakni dalam studi perhotelan dapat memeriksa pengaruh dalam job resourcefulness dengan individual crafting dikarenakan karyawan perhotelan terlibat dalam pekerjaan yang mengalami permasalahan sewaktu-waktu, oleh karena itu karyawan dengan job resourcefulness yang tinggi akan mendorong keinginan karyawan dalam mengubah prosedur pekerjaan, meningkatkan kapasitas dan kemampuan mereka untuk menyelesaian pekerjaannya (individual crafting) dalam kondisi dengan sumber daya yang terbatas sebaik-baiknya.

Studi ini tidak sejalan dengan Wang et al. (2016) bahwa karyawan dengan job resourcefulness yang tinggi dapat menentukan serta memiliki strategi yang berbeda-beda untuk menyusun pekerjaan mereka, tetapi tidak semua strategi job crafting tersebut akan membawa hasil yang positif dan mencapai apa yang diinginkan dari setiap karyawan tersebut, salah satu penyebabnya adalah kelelahan dan tekanan pekerjaan yang banyak, sehingga apabila karyawan mengalami kelelahan akan mengurangi tuntutan pekerjaan yang direncanakan serta berdampak terhadap tidak efektifnya strategi mereka.

\section{Pengaruh Job Resourcefulness terhadap Collaborative Crafting}

Hasil penelitian gagal membuktikan pengaruh job resourcefulness terhadap collaborative crafting karyawan hotel bintang 4 di kota Surabaya versi Traveloka. Hal ini bermakna bahwa tingkat job resourcefulness tidak berpengaruh terhadap collaborative crafting karyawan. Hasil pada studi ini menjelaskan bahwa karakteristik karyawan dengan job resourcefulness yang tinggi perlu dipertimbangkan suatu perusahaan dalam menerapkan sistem collaborative crafting dalam pekerjaannya.

Hasil yang tinggi menunjukkan bahwa karyawan hotel bintang 4 di kota Surabaya versi Traveloka telah menerapkan collaborative crafting dalam pekerjaannya. Sejalan dengan studi dari Tims \& Bakker (2010), job crafting dapat dilihat sebagai bentuk yang spesifik dari perilaku proaktif karyawan untuk memulai perubahan dalam pekerjaannya dan inisiatif dalam perubahan ini karena terdorong job resourcefulness dari karyawan. Namun, fokus dari job resourcefulness ini adalah individu, sehingga karyawan cenderung lebih mengalami kesejahteraan ketika saat melakukan perubahan pekerjaannya secara individu dikarenakan sesuai dengan preferensi masing-masing individu dan sesuai dengan kebutuhan dari individu tersebut. Oleh karena itu, karyawan yang terus berkembang termotivasi untuk mendesain ulang pekerjaan mereka secara individu bukan secara kelompok. Sehingga, antar karyawan memiliki beberapa pandangan yang tidak dapat disatukan dalam collaborative crafting (Wingerden et al., 2017). Unsur yang memengaruhi dalam collaborative crafting salah satunya adalah connecting leadership yang berarti bahwa peran seorang pemimpin dalam tim kerja berfungsi sebagai perangsang 
Yahdi Ariski \& Dwiarko Nugrohoseno. Efek Mediasi Variabel Work Engagement dalam Pengaruh Job Resourcefulness terhadap Individual Crafting dan Collaborative Crafting

bagi kesuksesan sebuah tim sehingga pengaruh yang negatif dapat disebabkan dari adanya pemimpin yang kurang maksimal dalam mengarahkan keberhasilan suatu tim kerja (Mäkikangas et al., 2017).

Studi ini tidak sejalan dengan hasil dari studi Chen (2019) yang menyatakan bahwa job resourcefulness memiliki pengaruh yang signifikan positif terhadap collaborative crafting dikarenakan karyawan dengan job resourcefulness yang tinggi akan mendorong kolaborasi antar karyawan secara bersama untuk memberikan layanan yang terbaik kepada pelanggan perusahaan. Dengan demikian, tingginya job resourcefulness karyawan hotel bintang 4 di kota Surabaya versi Traveloka memengaruhi secara negatif dan menurunkan collaborative crafting mereka secara langsung, namun penulis percaya bahwa meningkatnya job resourcefulness dalam kondisi tertentu akan memengaruhi tingkat collaborative crafting karena karyawan dengan tingkat job resourcefulness yang tinggi akan menemukan metode kreatif untuk menangani adanya collaborative crafting dengan menerapkan cara-cara inovatif seperti saling bertukar pikiran dan saling menerima masukan serta pendapat Cheng \& Chen (2017).

\section{Pengaruh Job Resourcefulness terhadap Work Engagement}

Hasil pengujian diketahui bahwa bahwa job resourcefulness berpengaruh signifikan positif terhadap work engagement. Hubungan yang positif menunjukkan apabila karyawan yang memiliki banyak akal dan mampu menghadapi tantangan atau masalah dalam pekerjaannya semakin merasa terlibat dalam pekerjaan yang dilakukkannya, besar nilai mean deskriptif responden pada variabel work engagement memiliki nilai yang masuk kedalam kategori tinggi, hal ini berarti karyawan hotel bintang 4 di Kota Surabaya versi Traveloka telah merasakan adanya work engagement dalam pekerjaan yang dilakukannya.

Hasil studi ini mendukung studi yang dilakukan oleh Chen (2019) mengungkapkan bahwasannya karyawan yang memiliki job resourcefulness yang tinggi cenderung melibatkan dirinya dalam pekerjaan yang dilakukannya. Hal itu dapat terjadi karena karyawan yang memiliki work engagement yang tinggi berkomitmen terhadap pekerjaan mereka sehingga mereka memanfaatkan akal pikiran mereka untuk menyelesaikan pekerjaannya dengan baik (Arasli et al., 2017). Cheng \& Chen (2017) mengungkapkan dalam studinya bahwa ketika karyawan dengan job resourcefulness yang tinggi bekerja di perusahaan yang memiliki sumber daya yang terbatas, maka mereka akan menyesuaian diri mereka dalam pekerjaannya untuk merespon lebih efektidd terhadap sumber daya yang terbatas, dan meningkatkan work engagement mereka dalam pekerjaan yang dilakuknnya. Sedangkan, studi Ashill et al. (2020) tidak sejalan dengan hasil studi ini yang menjelaskan bawah job resourcefulness tidak berpengaruh secara signifikan terhadap variabel work engagement.

\section{Pengaruh Work Engagement terhadap Individual Crafting}

Hasil uji pengaruh ini diketahui bahwa bahwa work engagement berpengaruh signifikan dengan arah yang positif terhadap individual crafting. Pengaruh yang signifikan ini apabila dikaitkan dengan hasil jawaban responden menunjukkan nilai kategori tinggi dan nilai indikator yang memiliki nilai tertinggi adalah dedication, yang artinya bahwa karyawan hotel bintang 4 di Kota Surabaya versi Traveloka antusias dengan pekerjaan yang dilakukannya, merasa terinspirasi oleh pekerjaannya, dan bangga dengan pekerjaan yang dilakukan oleh masing-masing karyawan. Nilai mean jawaban responden pada variabel individual crafting tergolong dalam kategori tinggi sehingga karyawan hotel bintang 4 di kota Surabaya versi Traveloka telah menerapkan adanya individual crafting dalam pekerjaannya.

Mäkikangas (2018) menjelaskan bahwa job crafting dari seseorang dapat dimunculkan melalui strategi yang digunakan karyawan dalam mengubah batasan pekerjaannya, dan strategi tersebut yang menentukan keberhasilan karyawan dalam pekerjaannya, sehingga karyawan akan semakin terlibat dalam pekerjaannya. Hal ini didukung oleh hasil studi oleh Naseem dan Sobia (2019) yang menyatakan bahwa kreativitas dalam aktivitas pekerjaan yang dilakukan oleh karyawan akan berdampak kepada meningkatnya work engagement dan secara langsung mengarah kepada hasil pekerjaan yang lebih baik. 
Work engagement melibatkan proses psikologis yang sangat penting di mana pekerjaan yang dihadapi oleh karyawan cenderung memengaruhi job crafting baik secara individual ataupun collaborative, sehingga keterlibatan karyawan yang tinggi dalam pekerjaannya meningkatkan dan mendorong proses mendesain ulang pekerjaan oleh karyawan (Chen, 2019). Namun, hasil yang berbeda terdapat pada studi Nguyen et al. (2019) yang menyatakan bahwa individual crafting dengan membangun hubungan dan menciptakan citra diri sendiri hanya cukup membantu menyelesaikan tugas, tidak cukup kuat untuk menciptakan vigor, dedication, dan arbsorption dalam pekerjaan.

\section{Pengaruh Work Engagement terhadap Collaborative Crafting}

Hasil pengujian pengaruh work engagement secara langsung pada collaborative crafting dalam studi ini diketahui bahwa menunjukkan work engagement berpengaruh signifikan dengan arah yang positif terhadap collaborative crafting. Hasil ini diperoleh berdasar data dari tabel path coefficient yang menunjukan nilai $t$-statistic memiliki nilai lebih besar dari nilai $t$-table. Implikasinya adalah ketika work engagement karyawan dalam perusahaan meningkat, hal ini juga akan meningkatkan collaborative crafting karyawan dalam pekerjaannya karena efek positif yang berbanding lurus.

Hasil nilai mean responden work engagement adalah tinggi yang berarti bahwa karyawan hotel bintang 4 di kota Surabaya versi Traveloka telah menerapkan adanya work engagement dalam pekerjaan yang mereka lakukan dalam perusahaannya. Hasil yang didapat pada nilai mean responden pada variabel collaborative crafting yang termasuk kedalam kategori tinggi. Hal ini menyatakan apabila perilaku collaborative crafting ini telah dilakukan oleh karyawan dalam melakukan tugastugas dalam pekerjaannya sehingga berbanding lurus dengan kategori tinggi tersebut.

Hasil studi ini mendukung studi oleh Alonso \& Topa (2019) bahwa karyawan dengan tingkat individual crafting yang tinggi terlibat dalam aktivitas atau strategi pekerjaannya, akan meningkatkan juga keterlibatannya dalam collaborative crafting dan mengakibatkan tingkat work engagement juga akan meningkat secara signifikan dikarenakan skala yang digunakan pada individual crafting dan collaborative crafting adalah valid dan menjadi dua hal yang tidak bisa disamakan. Studi dari Tims et al. (2013b) juga menjelaskan bahwa karyawan yang bekerja dalam tim akan memungkinkan lebih terlibat dalam pekerjaan serta mencakup pekerjaan yang dilakukan oleh individu, maka dari itu work engagement dalam collaborative crafting juga akan terkait dalam work engagement dalam individual crafting dikarenakan bekerja secara tim mencakup lebih luas dari pekerjaan yang dilakukan oleh individu.

Namun hasil yang berbeda ditemukan pada studi oleh Fazriati \& Budiono (2017) yang menyatakan bahwa tidak adanya pengaruh antara variabel work engagement terhadap job crafting dikarenakan tidak semua karyawan menerapkan dan melakukan collaborative crafting dalam pekerjaannya, dan untuk membuat karyawan memiliki work engagement dalam pekerjaannya dapat juga dipengaruhi oleh lingkungan yang nyaman dalam pekerjaannya maka karyawan tersebut akan merasa adanya dorongan positif serta merasa engaged dengan pekerjaannya. Dengan demikian, tingginya work engagement karyawan hotel bintang 4 di kota Surabaya versi Traveloka memengaruhi secara positif dan signifikan terhadap collaborative crafting mereka secara langsung.

\section{Pengaruh Job Resourcefulness terhadap Individual Crafting melalui Work Engagement}

Pengujian secara indirect dapat menjelaskan adanya pengaruh secara tidak langsung dan memiliki arah yang positif dari job resourcefulness terhadap individual crafting melalui work engagement. Hasil juga menunjukkan nilai $t$-statistic pengaruh tidak langsung antara job resourcefulness terhadap individual crafting melalui work engagement sehingga pengaruh job resourcefulness terhadap individual crafting melalui work engagement terdapat pengaruh signifikan dan variabel work engagement mampu memediasi pengaruh tersebut.

Studi yang telah ada oleh Chen (2019) menjelaskan bahwa karyawan yang memiliki banyak pekerjaan cenderung memecahkan masalah yang terkait dengan pekerjaan dan berbeda dengan karyawan pasif yang memandang masalah pekerjaan sebagai penghalang untuk menyelesaikan pekerjaannya, oleh 
Yahdi Ariski \& Dwiarko Nugrohoseno. Efek Mediasi Variabel Work Engagement dalam Pengaruh Job Resourcefulness terhadap Individual Crafting dan Collaborative Crafting

karena itu karyawan yang memiliki job resourcefulness yang tinggi dapat dianggap sebagai pelopor yang menemukan dan dapat memecahkan masalah dengan pelanggan serta dapat meningkatkan layanan mereka secara efisien karena secara tidak langsung memiliki engagement yang tinggi dan mengakibatkan mereka memutuskan untuk merubah dan mendesain ulang pekerjaan mereka sesuai dengan kompetensi masing-masing orang.

\section{Pengaruh Job Resourcefulness terhadap Collaborative Crafting melalui Work engagement Karyawan}

Uji statistik yang dilakukan adanya pengaruh tidak langsung dan memiliki arah yang positif dari variabel job resourcefulness terhadap collaborative crafting melalui work engagement. Hasil juga menunjukkan nilai $t$-statistic pengaruh tidak langsung antara job resourcefulness terhadap collaborative crafting melalui work engagement sehingga pengaruh job resourcefulness terhadap collaborative crafting melalui work engagement terdapat pengaruh signifikan.

Hal ini menunjukkan bahwa work engagement memiliki peran penting sebagai variabel perantara dalam memberikan pengaruh antara job resourcefulness terhadap collaborative crafting. Semakin besar job resourcefulness karyawan, semakin meningkat work engagement karyawan yang diikuti oleh meningkatnya collaborative crafting karyawan hotel bintang 4 di kota Surabaya versi Traveloka secara signifikan hal ini dikarenakan arah positif yang berarti hasil pengaruh berbanding lurus. Studi oleh Karatepe dan Aga (2012) menjelaskan bahwa job resourcefulness oleh karyawan menentukan adanya work engagement dalam pekerjaan mereka, meskipun dihadapkan oleh sumber daya yang terbatas dan terjadinya kelangkaan sumber daya, karyawan yang memiliki job resourcefulness memiliki kemampuan untuk melaksanakan tugas-tugas terkait pekerjaan mereka dengan sukses. Artinya, karyawan yang bekerja dalam perusahaan jasa memiliki kemampuan yang mumpuni untuk menangani permintaan dan masalah pelanggan sesuai dengan apa yang diharapkan pelanggan.

Hal tersebut juga didukung oleh Tims et al. (2013) bahwa job crafting secara individual akan memperluas kepada job crafting secara collaborative, secara keseluruhan ini menunjukkan bahwa hal tersebut secara aktif meningkatkan job resource dan akibatnya akan meningkatkan juga work engagement karyawan baik di tingkat individual crafting serta collaborative crafting. Studi ini juga didukung oleh hasil studi Chen (2019) yang menjelaskan bahwa work engagement sebagai mediator memiliki proses psikologis yang sangat penting di mana memperkuat hubungan job resourcefulness dan collaborative crafting di mana untuk meningkatkan cara kerja produktif tidak hanya memerlukan pekerjaan secara individu, namun secara berkolaborasi juga sangat diperlukan dalam kesuksesan perusahaan khususnya dalam bidang perhotelan yang terkait erat dengan pelayanan dan jasa sehingga perusahaan harus tetap menjaga kualitas dari layanan tersebut kepada pelanggan.

Efek job resourcefulness terhadap collaborative crafting melalui work engagement ini mampu menunjukkan bahwa ketika perusahaan memberikan ruang bagi karyawan untuk bereksplorasi dan berkreatifitas maka akan timbul job resourcefulness yang dari akal pikiran itu akan dialihkan menjadi suatu keadaan yang mengubah batasan dari pekerjaan karyawan tersebut secara bersama-sama. Sehingga, sikap tersebut akan meningkatkan work engagement karyawan yang mampu menyelesaikan pekerjaannya dengan baik dan tepat. Penjelasan ini memberikan suatu pemahaman bahwa untuk variabel work engagement dapat menjadi variabel mediasi antara job resourcefulness terhadap collaborative crafting.

\section{KESIMPULAN}

Job resourcefulness terbukti memiliki pengaruh langsung yang signifikan positif terhadap individual crafting dan memiliki pengaruh tidak langsung yang signifikan dan positif terhadap individual crafting melalui work engagement pada karyawan hotel bintang 4 di Kota Surabaya Versi Traveloka. Job resourcefulness ditemukan memiliki pengaruh langsung yang signifikan dan negatif terhadap collaborative crafting. Job resourcefulness memiliki pengaruh yang tidak langsung secara signifikan positif terhadap collaborative crafting melalui work engagement karyawan hotel bintang 4 di Kota 
Surabaya versi Traveloka. Penelitian selanjutnya dapat melibatkan variabel career commitment dan job \& life satistaction.

Implikasi pada studi ini yaitu perusahaan hotel bintang 4 yang termasuk dalam sampel studi ini perlu meningkatkan collaborative crafting karyawan dengan cara melibatkan seluruh karyawan dalam pengadaan forum diskusi, sehingga dapat menyelaraskan pemikiran antar karyawan yang ada dalam perusahaan sehingga dengan adanya forum tersebut akan ada kesamaan persepsi sehingga kolaborasi pekerjaan dapat terjalin dengan baik. Perusahaan dapat menggunakan hasil studi ini sebagai dasar dalam pengembangan job resourcefulness melalui work engagement untuk meningkatkan kualitas dari individual crafting dan collaborative crafting karyawan dalam perusahaan masing-masing.

\section{DAFTAR PUSTAKA}

Abdulah, A. T. B. (2021). Breaking News Update Corona Indonesia 3 Juni 2021: Tambah 5.353 Kasus Baru, 11.092 Pasien Sembuh Artikel ini telah tayang di Tribunnews.com https://www.tribunnews.com/corona/2021/06/03/breaking-news-update-corona-indonesia-3juni-2021-tambah-5353-kasus-baru-11092-pasien-sembuh, diakses 6 April 2021

Alonso, M. L., \& Topa, G. (2019). Individual Crafting, Collaborative Crafting, and Job Satisfaction: The Mediator Role of Engagement. Revista de Psicologia Del Trabajo y de Las Organizaciones, 35(3), 217-226. https://doi.org/10.5093/jwop2019a23

Anggita, V. (2020). Disiplin Protokol Kesehatan di Hotel Dorong Pemulihan Sektor Hospitality. SWA. https://swa.co.id/covid19/disiplin-protokol-kesehatan-di-hotel-dorong-pemulihan-sektorhospitality, Diakses 11 Desember 2020

Arasli, H., Teimori, R. B., Kilic, H., \& Aghaei, I. (2017). Effects of Service Orientation on Job Embeddedness in Hotel Industry. Service Industries Journal, 37(9-10), 607-627. https://doi.org/10.1080/02642069.2017.1349756

Ashill, N. J., Rod, M., Thirkell, P., \& Carruthers, J. (2020). Job Resourcefulness, Symptoms of Burnout and service recovery performance: An examination of call centre frontline employees. Journal of Services Marketing, 23(5), 338-350. https://doi.org/10.1108/08876040910973440

Badan Pusat Statistik. (2021). Jumlah kunjungan wisman ke Indonesia bulan Desember 2020 mencapai 164,09 ribu kunjungan. https://www.bps.go.id/pressrelease/2021/02/01/1796/jumlah-kunjungan-wisman-ke-indonesiabulan-desember-2020-mencapai-164-09-ribu-kunjungan-.html, diakses 7 Juli 2021

Bakker, A. B. (2017). Strategic and Proactive Approaches to Work Engagement. Organizational Dynamics, 46(2), 67-75. https://doi.org/10.1016/j.orgdyn.2017.04.002

Bakker, A. B., \& Leiter, M. P. (2010). Work Engagement A Handbook of Essential Theory and Research. New York: Psychology Press Taylor \& Francis Group

Bakker, A. B., Tims, M., \& Derks, D. (2012). Proactive Personality and Job Performance: The role of job crafting and work engagement. Human Relations, 65(10), 1359-1378. https://doi.org/10.1177/0018726712453471

Chen, C. Y. (2019). Does Work Engagement Mediate the Influence of Job Resourcefulness on Job Crafting?: An examination of frontline hotel employees. International Journal of Contemporary Hospitality Management, 31(4), 1684-1701. https://doi.org/10.1108/IJCHM-052018-0365 
Yahdi Ariski \& Dwiarko Nugrohoseno. Efek Mediasi Variabel Work Engagement dalam Pengaruh Job Resourcefulness terhadap Individual Crafting dan Collaborative Crafting

Cheng, J.-C., \& Chen, C.-Y. (2017). Job Resourcefulness, Work Engagement and Prosocial Service Behaviors in the Hospitality Industry. Of Contempory Hospitality Management. https://doi.org/https://doi.org/10.1108/ IJCHM-01-2016-0025

Fazriati, N. F., \& Budiono. (2017). Pengaruh Job Crafting terhadap Work Engagement yang dimediasi oleh Person Job Fit pada pt. berlian jasa teminal indonesia. Jurnal Ilmu Manajemen. 5 (3), 1-9.

Garg, S., \& Dhar, R. (2017). Article information: Employee Service Innovative Behavior: The Roles of Leader-Member Exchange ( LMX ), Work. International Journal of Manpower, Vol. 38(2), 1-42. https://doi.org/http://dx.doi.org/10.1108/IJM-04-2015-0060

Ghozali, I. (2006). Structural Equation Modeling Metode Alternatif dengan Partial Least Square (Edisi Keem). Semarang: Badan Penerbit Universitas Diponogoro.

Ghozali. I (2016). Aplikasi Analisis Multivariete Dengan Program IBM SPSS 23 (Edisi 8). In Universitas Diponegoro (8th ed.). Semarang: Badan Penerbit Universitas Diponegoro.

Jayani, D. H. (2020). Tingkat Penghunian Kamar (TPK) Menurut Klasifikasi Hotel Bintang di Indonesia (Oktober 2020). Databoks.Katadata.Co.Id. https://databoks.katadata.co.id/datapublish/2020/12/07/tingkat-penghunian-kamar-hotelbintang-4-tertinggi-pada-oktober-2020, Diakses 22 Januari 2021

Karatepe, O. M., \& Aga, M. (2012). Work Engagement as a Mediator of the Effects of Personality Traits on Job Outcomes: A Study of Frontline Employees. Services Marketing Quarterly, 33(4), 343-362. https://doi.org/10.1080/15332969.2012.715053

Karatepe, O. M., \& Karadas, G. (2015). Do Psychological Capital and Work Engagement Foster Frontline Employees' Satisfaction?: A study in the hotel industry. International Journal of Contemporary Hospitality Management, 27(6), 1254-1278. https://doi.org/10.1108/IJCHM-012014-0028

Leana, C., Appelbaum, E., \& Shevchuk, I. (2009). Work Process and Quality of Care in Early Childhood Education: The role of job crafting. Academy of Management Journal, 52(6), 11691192. http://web.b.ebscohost.com/ehost/pdfviewer/pdfviewer?sid=de7848cd-d070-471f-998df6fb4eba229c\%40sessionmgr 102\&vid=1\&hid=128

Licata, J. W., Mowen, J. C., Harris, E. G., \& Brown, T. J. (2003). On the Trait Antecedents and Outcomes of Service Worker Job Resourcefulness: A Hierarchical Model Approach. Journal of the Academy of Marketing Science, 31(3), 256-271. https://doi.org/10.1177/0092070303252599

Lu, C. Q., Wang, H. J., Lu, J. J., Du, Y. D., \& Bakker, A. B. (2014). Does Work Engagement Increase Person-Job Fit? The role of job crafting and job insecurity. Journal of Vocational Behavior, 84(2), 142-152. https://doi.org/10.1016/j.jvb.2013.12.004

Mäkikangas, A. (2018). Job crafting profiles and work engagement: A person-centered approach. Journal of Vocational Behavior, 106, 101-111. https://doi.org/10.1016/j.jvb.2018.01.001

Mäkikangas, A., Bakker, A. B., \& Schaufeli, W. B. (2017). Antecedents of daily team job crafting. European Journal of Work and Organizational Psychology, 26(3), 421-433. https://doi.org/10.1080/1359432X.2017.1289920

Nguyen, H. M., Nguyen, C., Ngo, T. T., \& Nguyen, L. V. (2019). The Effects of Job Crafting on Work Engagement and Work Performance: A study of Vietnamese commercial banks. Journal 
of Asian Finance, Economics and Business, 6(2), 189-201. https://doi.org/10.13106/jafeb.2019.vol6.no2.189

Pebrianto, F. (2020). Awal 2020, Pariwisata Indonesia Sudah “Terserang” Virus Corona. Tempo. https://bisnis.tempo.co/read/1314447/awal-2020-pariwisata-indonesia-sudah-terserang-viruscorona/full\&view=ok, diakses 11 Desember 2020

Pranita, E. (2020). Diumumkan Awal Maret, Ahli: Virus Corona Masuk Indonesia dari Januari. Kompas. https://www.google.com/amp/s/amp.kompas.com/sains/read/2020/05/11/130600623/diumumka n-awal-maret-ahli--virus-corona-masuk-indonesia-dari-januari, Diakses 11 Desember 2020

Rod, M., \& Ashill, N. J. (2009). Symptoms of Burnout and Service Recovery Performance: The Influence of job Resourcefulness. Managing Service Quality, 19(1), 60-84. https://doi.org/10.1108/09604520910926818

Schaufeli, W. B., Salanova, M., Roma, V. G., \& Bakker, A. B. (2002). The Measurement of Engagement and Burnout: A Two Sample Confirmatory Factor Analytic Approach. Journal of Happiness Studies, 3(1), 71-92. https://doi.org/10.1023/A:1015630930326

Semedo, A. S. D., Coelho, A. F. M., \& Ribeiro, N. M. P. (2016). Effects of Authentic Leadership, Affective Commitment and Job Resourcefulness on Employees' Creativity and Individual Performance. Leadership \& Organization Development Journal, 37(8). https://doi.org/http://dx.doi.org/10.1108/LODJ-02-2015-0029

Siregar, S. (2014). Statistik Parametrik untuk Penelitian Kuantitatif: dilengkapi dengan perhitungan manual dan aplikasi SPSS versi 17 (Edisi 1). Makassar: Bumi Angkasa.

Sonnentag, S. (2003). Recovery, Work Engagement, and Proactive Behavior: A New Look at the Interface Between Nonwork and Work. Of Applied Psychology, 88(2003), 518-528.

SWAonline. (2020). Strategi Jitu Transformasi Digital, untuk Bangkit dan Kompetitif di Era "NEW NORMAL" \& Post COVID-19. SWA. https://swa.co.id/swa/trends/strategi-jitu-transformasidigital-untuk-bangkit-dan-kompetitif-di-era-new-normal, diakses 11 Desember 2020

Team, T. (2020). Bawa Pulang 2 Penghargaan Sekaligus, Traveloka Buktikan Diri Perusahaan Teknologi Terdepan Indonesia. M.Traveloka.Com. https://m.traveloka.com/idid/explore/tips/bawa-pulang-2-penghargaan-sekaligus-traveloka-buktikan-diri-perusahaanteknologi-terdepan-indonesia/14003, diakses 6 April 2021

Tims, M., Bakker, A. B., \& Derks, D. (2012). Development and Validation of The Job Crafting Scale. Journal of Vocational Behavior, 80(1), 173-186. https://doi.org/10.1016/j.jvb.2011.05.009

Tims, M., Bakker, A. B., Derks, D., \& Rhenen, V. W. (2013a). Job Crafting at the Team and Individual Level: Implications for Work Engagement and Performance. Group \& Organization Management, 38(4), 427-454. https://doi.org/10.1177/1059601113492421

Tims, M., Bakker, A. B., \& Derks, D. (2013b). The impact of job crafting on job demands, job resources, and well-being. Journal of Occupational Health Psychology, 18(2), 230-240. https://doi.org/10.1037/a0032141

Tims, M., \& Bakker, A. B. (2010). Job crafting: Towards a New Model of Individual Job Redesign. SA Journal of Industrial Psychology, 36(2), 12-21. https://doi.org/10.4102/sajip.v36i2.841 
Yahdi Ariski \& Dwiarko Nugrohoseno. Efek Mediasi Variabel Work Engagement dalam Pengaruh Job Resourcefulness terhadap Individual Crafting dan Collaborative Crafting

Traveloka. (2019). Traveloka Ranked as The Most Popular Ticket and Hotel Booking Application Among Millennials. TravelokaPress. http://press.traveloka.com/traveloka-ranked-popularbooking-application-among-millennials/, diakses 22 Januari 2021

Van Wingerden, J., Derks, D., \& Bakker, A. B. (2017). The Impact of Personal Resources and Job Crafting Interventions on Work Engagement and Performance. Human Resource Management, 56(1), 51-67. https://doi.org/10.1002/hrm.21758

Wahyudi, E. (2020). HRI: Sektor Pariwisata Rugi Rp 85,7 Triliun Akibat Pandemi. TEMPO.CO. https://bisnis.tempo.co/read/1365055/phri-sektor-pariwisata-rugi-rp-857-triliun-akibatpandemi/full\&view=ok, Diakses 29 Desember 2020

Wang, H., Demerouti, E., \& Bakker, A. B. (2016). A review of job crafting research: The role of leader behaviors in cultivating successful job crafters. Proactivity at Work: Making Things Happen in Organizations, December, 77-104. https://doi.org/10.4324/9781315797113

Wrzesniewski, A., \& Dutton, J. E. (2001). Crafting a Job: Revisioning Employees as Active Crafters of Their Work. Academy of Management Review, 26(2), 179-201. https://doi.org/10.5465/AMR.2001.4378011

Xanthopoulou, D., Bakker, A. B., Demerouti, E., \& Schaufeli, W. B. (2009). Reciprocal Relationships Between Job Resources, Personal Resources, and Work Engagement. Journal of Vocational Behavior, 74(3), 235-244. https://doi.org/10.1016/j.jvb.2008.11.003 